\title{
MENINGKATKAN KESADARAN INDIVIDU MELALUI AJARAN KARMAPHALA
}

\author{
I Made Hartaka ${ }^{(1)}$ Ni Made Yunitha Asri Diantary(2) \\ STAHN Mpu Kuturan Singaraja
}

\begin{abstract}
Human behavior determines the results they will receive later. Rational thinking continues to look for the true meaning of life that we live today. with the ability to receive knowledge empirically or based on literacy sources, humans look for the right equivalent of the life they have received from birth to death. The deepening of faith continues to be carried out in the hope of enlightening the search for answers to these questions. The doctrine of teaching has been given concretely, that life is influenced by our past, present, and future behavior. Literary sources become doctrines that are held by Hindus to navigate the ocean of life. The current period requires humans to quickly make decisions. Thoughts about how we behave are suggested to accommodate this. But many are trapped by the desire to follow developments that ignore religious noble values. Self-discipline needs to be improved, so that someone returns to the path of Dharma based on the Vedic scriptures.
\end{abstract}

\section{Keywords: Increase, Individual Awareness, Karmaphala}

\section{PENDAHULUAN}

Manusia sebagai makhluk sosial sangat bergantung pada manusia lain disekitarnya untuk bertahan hidup, karena manusia memiliki banyak keterbatasan walau kerap disebut sebagai makhluk yang utama dan mulia. Hidup bersama dalam suatu kelompok memiliki konsekunsi terhadap tingkah pola yang dilakukan individu bersangkutan. Saling pengertian, saling menghargai dan menahan ego harus dilakukan agar tercipta keteraturan dan kenyaman bersama. Jika tidak dilakukan berdampak pada munculnya perselisihan yang berakibat pada sikap-sikap yang mencerminkan sisi kemanusiaan. Hukum rimba menjadi cara menyelesaikan perselisihan. Pemiliki kekuatan dan kuasa akan mengintimidasi yang lemah.
Dewasa ini, tindakan kekerasan hampir selalu menjadi alat untuk memperjuangkan segala macam bentuk ideologi, apakah itu soal kemerdekaan, kebenaran, kedamaian, keadilan ataupun sekedar cita-cita. Seolah kekerasan adalah jalan sahih, atau mungkin satusatunya, untuk menemukan semua ambisi itu. Ada semacam keyakinan bahwa situasi dapat diubah atau nilai hakiki serta martabat manusia dapat ditegakkan hanya melalui Tindakan kekerasan dan unjuk kekuatan (Segara, 2019: 1).

Veda adalah Pustaka suci Hindu yang tidak semata-mata berbicara tentang hal-hal yang bersifat metafisiseskatologi, tetapi juga berbicara tentang hal-hal praktis kehidupan manusia seperti hubungan manusia dengan sesamanya dan hubungan manusia dengan alam (Gorda, 2006:34). Ini 
menunjukkan bahwa ajaran dalam Veda kaya akan gagasan, pesan, dan nilai yang digunakan sebagai pedoman dalam berprilaku dalam menghadapi berbagai tantangan hingga menembus lintas batas waktu.

Manusia menurut ajaran Hindu untuk hidup bahagia harus memahami beberapa hal, dalam Slokantara (38) menyebutkan ada empat golongan manusia yang menikmati kebahagiaan yakni: orang yang tahu tujuan dan cara hidup, orang yang pemberani, orang yang bijaksana, dan orang yang pandai berbicara ramah dan baik. Kehiduapan manusia yang cepat berlalu mendorong agar senantiasa berbuat baik. Maharsi Vararuci dalam sarasamuscaya (8) menggambarkan kehidpuan manusia layaknya cahaya kilat yang sangat susah didapat dan begitu cepat berlalu, sehingga dalam kehidupan ini hendaknya berusaha dengan sungguhsungguh berprikalu berdasarkan sadhana dan dharma untuk menghapus kesengsaraan.

Pedoman untuk memahami kehidupan diturunkan Beliau melalui wahyu (sruti) yang diterima oleh para Maharsi kemudian ditafsirkan (smrti) dalam berbagai ajaran agama, selanjutnya bagaimana kita patuh dan taat mengikutinya sebagai bekal guna mengarungi bahtera kehidupan. Bila ajaran agama atau keyakinan terhadap Tuhan Yang Maha Esa diaktualisasikan dengan baik, tentu ketentraman masyarakat akan terwujud. Akan tetapi kenyataan dilapangan acapkali merupakan kontradiski ajaran suci agama. Dalih kebenaran ajaran agama, orang lain atau keyakinannya lebih rendah bahkan hina dari apa yang dipahami. Hingga muncul cenderung untuk melibas yang yang berbeda tersebut.

Agama adalah institusi yang memuat seperangkat peraturan, perintah, dan larangan dengan tujuan mengatur kehidupan manusia secara duniawi dan spiritual. Institusi agama dengan segenap peraturanya, berasal dari luar diri manusia, sehingga bisa dikatakan agama adalah bagian dari lingkungan eksternal manusia. Dalam konteks psikologi, agama bisa dianggap sebagai stimulus yang memerlukan respon para pemeluknya (Saifuddin, 2019: 179).

Pemikiran diatas menunjukkan bila kita memahami secara utuh dan seksama, kebaikan agama terletak pada penganutnya. Pertanyaan yang harus kita jawab apakah ajaran yang dianut tersebut telah dilaksanakan dengan benar. Jika telah dilaksanakan dengan benar tentu terwujudnya ketentraman dan kesejahtraan hidup baik dalam keluarga, masyarakat, bangsa dan negara bukan merupakan mimpi atau wacana semata.

Ketertekanan dalam kehidupan, mengakibatkan manusia tidak lagi bisa dan mampu menumbuhkembangkan secara optimal kesadaran yang fitri (suci) pada dirinya. Kesadaran merupakan nilai lebih yang diberikan Tuhan kepada manusia. Tertutupnya kesadaran diri, menjadikan manusia semakin jauh dari tujuan hidup sesungguhnya (Buditha, 2019: 2).

Pemahaman ajaran Karmaphala dapat dperkuat dengan mengkaji beberapa sumber dan petuah dari para guru (sabda pramana) serta pengamatan empirik (pratyaksa). terdapat pemikiran yang mengungkapkan kejadian pandemi yang terjadi saat ini merupakan klimaks dari degradasi moral yang terjadi selama kurun waktu belakangan ini. Peningkatan kualitas diri dan 
merealisasikan ajaran agama khususnya ajaran Karmaphala diharapkan dapat meningkatkan kesadaran individu sebagai seorang manusia seutuhnya.

\section{PEMBAHASAN}

\subsection{Dasar Keyakinan Agama Hindu}

Manusia memiliki kemampuan untuk belajar dari sebuah permasalahan yang dialami menjadi pengetahuan yang berguna bagi diri dan lingkungannya. Pada tahap selanjutnya pengetahuan dijadikan ilmu yang dapat diturunkan menjadi ilmu Teknik, kedokteran, perdagangan, sosial politik, budaya, agama dan sebagainya. Kemampuan tersebut dimanfaatkan dalam produktivitas kerja yang menghasilkan pemasukan secara finasial. Alam material semacam ini mempunyai daya tarik yang sangat luar biasa. Kemewahan membuat seseorang silau dan tergiur untuk meraihnya. Ketika telah diraih pun seakan tak cukup untuk memuaskan hasrat yang ada. Pengetahuan rohani menjadi jalan untuk memahami esensi dari kehidupan di dunia. Agama sebagai sebuah ilmu menjelaskan bagaimana cara dan tahapan yang harus dilakukan manusia untuk menemukan kebahagiaan yang sejati.

Kata Agama yang dipergunakan oleh umat Hindu penganut mashab Siwa dan dipakai dalam Bahasa Indonesia sebagai istilah kerohanian berasal dari bahasa Sanskerta, dari akar kata "gam", yang berarti pergi. Kalau "gam" diberi awalan "A" menjadi "Agam" yang berarti kebalikan dari pergi, yaitu datang, dan bila diberi akhiran "a" kemudian menjadi kata Agama, artinya kedatangan (Punyatmadja, 2019: 1)

Agama diciptakan dengan tujuan utama menciptakan keseimbangan di dalam kehidupan. Keseimbangan ini bisa bermacam-macam wujudnya. Keseimbangan dapat terbentuk salah satunya dengan memberikan batasan pada perilaku manusia. Baik perilaku manusia kepada dirinya sendiri, kepada sesama manusia, kepada sesama makhluk hidup, maupun kepada alam semesta (Saifudin, 2019: 231).

Agama Hindu tidak berdasarkan hanya atas kepercayaan tertentu. Ia didasari teori keagamaan yang benar yang tidak dapat dibuktikan kepalsuannya. Ia tidak menjadikan suatu cara yang istimewa untuk melakukan kehidupan beragama. Pengikut-pengikut Hindu sewaktu-waktu bersedia untuk menerima tiap-tiap kebenaran yang didapat orang dimanapun juga. Ini membuktikan kecintaan orang Hindu terhadap kebenaran yang sejati. Nilai dan ajaran agama Hindu telah mampu diterima semua sarjana yang ada di seluruh belahan dunia.

Nilai-nilai dalam ajaran agama sering dipersepsikan mulia bahkan sakral, namun perlu digarisbawahi nilainilai tersebut harus membumi, yang dapat diartikan ajaran tersebut bukan hanya menjadi penghias dalam bukubuku suci. Internalisasi ajaran kedalam diri yang selanjutnya diimplementasikan dalam kehidupan yang dilakoni oleh umatnya. Nilai ini menjadi dasar pondasi akhlak yang ada dalam masyarakat. Menjawab setiap persoalan dalam awal kehidupan, proses pendewasaan, dan berkahir pada kematian. Seluruh ajaran Hindu bisa dipadatkan dalam satu wadah Panca Sradha, yakni butir-butir utama keyakinan (keimanan) Hindu, yang diarahkan kepada keyakinan kepada Tuhan, Atman, hukum sebab akibat, reinkarnasi, dan kedamaian abadi (Vidhi atau Brahman, Atman, Karmaphala, Samsara, dan Moksa Sradha) (Gorda, 2006: 51).

Dilihat dari tiga kerangka dasar Agama Hindu, Isi kitab suci Veda dapat juga meliputi pengelompokan tersebut yang terdiri dari: (1) Ajaran tentang Sradha atau Tattva, (2) Susila dan (3) Acara Agama (Titib, 2011: 149). Makna kata Sradha yang kiranya amat sulit 
mencari padanannya kata benar-benar tepat dalam kosa kata bahasa Indonesia. Selanjutnya yang mana saja dalam Agama Hindu dapat dikategorikan ke dalam Sradha. Sradha merumuskannya lima jenis keyakinan atau keimanan Hindu yang dijadikan pedoman, yaitu:

a. Widhi Sradha, yaitu keyakinan atau keimanan terhadap adanya Tuhan Yang Maha Esa termasuk dengan berbagai manifestasinya

b. Atma Sradha, yaitu keimanan terhadap keberadaan Atma yang menghidupi semua makhluk di dunia.

c. Karmaphala Sradha, yaitu keimanan terhadap kebenaran hukum sebab akibat yang mengikat tingkah pola makhluk hidup

d. Punarbhawa Sradha, yaitu keimanan terhadap proses kelahiran berulang

e. Moksa Sradha, yaitu keimanan terhadap kebebaasan tertinggi atau bersatunya sang atman dengan brahman sebagai sumber kehidupan (Titib, 2006: 168).

Sradha adalah keyakinan yang merupakan pondasi dalam agama Hindu. Keyakinan ini merupakan standar yang dipegang sebagai dasar berperilaku oleh setiap umat Hindu. Ajaran Panca Sradha ini dengan dipahami mendalam bukan hanya untuk pengetahuan semata tanpa direalisasikan di kehidupan nyata, maka tidak ada faedahnya untuk mendalami ajaran Sradha.

Widhi Sradha sebagai dasar keyakinan pertama, memiliki kedudukan utama dimana keimanan mutlak tetang keberadaan Tuhan (Widhi atau Brahman). Guna memperkuat dasar keimanan ini perlu mencari sumber rujukan dari kitab suci Veda. Adapun mantra Veda yang menunjukkan hubungannya dengan keimanan terhadap Tuhan, yaitu.

\section{Brahmana bhumir vihita Brahma dyaur uttara hita}

Brahma-idam urdhvam tiryak ca-

Antariksam vyaco hitam.

(Atharvaveda X.2.25)

Terjemahan:

Brahman menciptakan bumi ini. brahman menempatkan langit ini di atanya. Brahman menempatkan wilayah tengah yang luas ini di atas dan di jarak lintas.

\section{Brahman devan anu ksiyati \\ Brahma daivajanir visah \\ Brahmedam anyat-naksatram \\ Brahma sat ksatram ucyate.}

(Atharvaveda X.2.23)

Terjemahan:

Tuhan yang Maha Esa bersemayam dan berwujud sebagai para dewa. Tuhan Yang Maha Esa, bersemayam pada media-media yang suci. Tuhan Yang Maha Esa adalah abadi (tak terhancurkan) dan Dia adalah Pelidung yang ulung (Titib, 2006: 169-170)

Keimanan selanjutnya ilalah keyakinan adanya atma yang ada dalam tubuh semua makhluk. Atman sebagai percikan api Tuhan (Brahman, Paramatman) merupakan sebab bagi gerak dan hidup manusia individual. Oleh karena itu atman juga disebut sebagai jiwatman. Hal ini menjadi salah satu dasar kesradhaan (keimana) Hindu (Gorda, 2006: 53-54)

\section{na jayate mriyate va kadacin nayam bhutva bhavita van a bhuyah ajo nitya sasvato yam purano na hayate hayamane sarire}

(Bhagavadgita II.20)

Terjemahan:

Ia tidak pernah lahir pun juga tidak pernah mati kapanpun, pun juga tidak pernah muncul dan lagi tidak pernah menghilang. Ia adalah tidak mengenal 
kelahiran, kekal, abadi dan selalu ada. Ia tidak dapat dibunuh bila badan dibunuh.

\section{Vasamsi jirnani yatha vihaya \\ Navani grhnati naro parani \\ Tatha sarirani vihaya jirnany \\ Anyani samyati navana dehi.}

(Bhagavadgita II. 22)

Terjemahan:

Sebagaimana seseorang melemparkan bajunya yang sudah robek dan memakai yang baru, demikian juga keadaan jiwa yang sejati, jiwanya, membuang badan yang telah hancur dan mengambil yang lain (Mantra, 2018: 3536).

Karma atau perbuatan, menentukan perpindahan atau kelahiran baru daripada jiwa. Kelahiran saat ini ditentukan oleh perbuatan kita dalam kehidupan yang terdahulu dan perbuatan kita sekarang menentukan bagaimana kelahiran kita di masa yang akan datang. Seperti dalam sloka diatas bahwa jiwa itu tidak akan pernah mati, ini akan dapat menjawab bagaimana seseorang dapat terlahir bahagia dengan kesehatan baik, fisik sempurna, pemikiran jernih, sedangkan disisi yang berbeda ada yang lahir penuh dengan ketidaksempurnaan.

Ya indra sasti-avrato-

Anusvapam adevayuh

(Rgveda VIII.97.3)

Terjemahan:

Ya Tuhan Yang Maha Esa, orang yang malas adalah orang yang tidak beriman, tidak giat, dan mengutuk, mati dari perbuatannya sendiri

Adhursata svayam ete vacobhir,

Rjuyate vrjinani bruvantah.

Terjemahan:

Orang-orang yang tidak berjalan lurus seperti aku, dihancurkan karena kesalahan-kesalahan mereka sendiri (Titib, 2006: 188-189)

Kematian hanya berarti berhentinya kerja alat-alat fisik atau terpisahnya badan rohani dengan jasmani. Atma tetap bekerja dan sesuai rencana menuju tempat sejlanjutnya. Jika dapat analogikan secara sederhana kondisi ini layaknya kondisi tidur dengan bermimpi, dimana terdapat kesadaran dalam kondisi fisik yang tidak bergerak. Atma akan berpindah dan terus berpindah selam masih memiliki ikatan dengan karma.

\section{Dehino smin jatha dehe \\ Kaumaram yauvanam jara \\ Tatha dehantarapratir \\ Dhiras tatra na muhyati}

(Bhagavadgita II.13)

Terjemahan:

Sebagai jiwa melalui badan ini pada waktu kita kecil, muda dan tua begitu juga di dalam masuknya ke badan yang lain, jiwa yang tenang itu tak dipengaruhi oleh keadaan proses ini (Mantra, 2018: 32)

Punarbhawa hanya akan berakhir jika kita mampu melepaskan ikatan dari hukum sebab akibat. Moksa adalah kondisi dimana sang atma telah mengalami kondisi tersebut. Moksa,mukti, atau nirvana dapat pula diartikan kemerdekaan, pelepasan dari ikatan karma, kelahiran, kematian dan penderitaan. Dengan pemahaman itu, maka moksa menjadi tujuan terakhir yang dicapai oleh umat Hindu. Kondisi ini dapat dicapai dengan empat jalan yang dikenal dengan istilah catur marga yoga, yaitu: bhakti marga yoga, karma marga yoga, jnana marga yoga dan raja marga yoga.

\section{Yena devah svar aruruhur \\ Hitva sariram amrtasya nabhim \\ Tena gesma sukrtasya lokam \\ Gharmasya vratena \\ tapasayasasya vah}

(Atharvaveda IV.11.6)

Terjemahan:

Dengan pertolongan Tuhan Yang Maha Esa orang-orang yang bijaksana, sesudah kematian memeproleh 
keselamatan, yang mencapai pusat nectar (minuman dewa) yakni kebahagiaan sejati. semoga kami yang berkeinginan kemashyuran, juga mencapai kekekalan itu, melalui pelaksanaan pertapaan yang keras dan menjalankan janji (brata) (Titib, 2006: 197)

\subsection{Pendalaman Ajaran Sradha}

Ajaran Sradha dapat disosialisasikan melalui metode Dharma wacana, Dharmatula, dan Dharmagìta. Parisada Hindu dharma Indonesia (PHDI) telah merumuskan hal tersebut sebagai upaya menyebarluaskan ajaran Dharma. Suksesnya atau tidaknnya usaha ini tentu nampak dengan bagaimana perilaku umat secara luas, maka lembaga pengkajian (termasuk pula penerjemahan), perpustakaan dan fasilitas lainnya termasuk lembaga pendidikan formal perlu bersinergi untuk mewujudnyatakan tujuan tersebut.

Pendalaman / penggalian Sradha bertujuan tidak lain dalam rangka pengamalan ajaran agama, oleh karena itu usaha untuk mensosialisasikan ajaran Sradha patut dikedepankan dan didukungan seluruh kalangan. Dalam usaha melakukan penggalian terhadap nilai Sradha bermacam usaha dapat dilakukan. penggalian Sradha melalui pendalam susastra suci Veda dan sumber literasi Hindu lainnya patut digalakkan. Usaha ini tengah digalakkan dengan perguruan tinggi agama dalam mengkaji dasar-dasar keagamaan (Hartaka, 2019). Buka bacaan keagamaan telah mulai banyak dibuat dan disusun, walau harus diakui hal tersebut perlu terus ditingkatkan guna memenuhi kehausan umat akan sumber bacaan. Tantangan juga merupakan tanggung jawab besar seluruh umat dalam menunjang pemahaman ajaran agama bagi generasi penerus.

Dalam rangka meningkatkan pendalaman ini, sangat kita rasakan sumber daya manusia Hindu yang masih harus ditingkatkan secara kualitas maupun kuantitas. Dewasa ini kita memerlukan banyak filolog (ahli) Sanskerta dan Jawa Kuno, ahli-ahli filsafat, sastra, sejarawan, hukum Hindu dan lain-lain. Tidaklah tepat kita berpangku tangan dan hanya menunggu lembaga agama untuk berbuat. usaha mengadakan Dharmatula secara periodik dengan topik-topik yang menyentuh keseharian umat. Diskusi yag dilakukan secara berkesinambungan tentu menjadi wadah mengajukan gagasan dan pemikiran yang dapat membangun. Gagasan tidaklah patut dilihat hanya sebagai bentuk ujuk gigi semata atau bahkan dijadikan pertentangan atau permusuhan, melainkan mencari bentuk terbaik dalam proses pendewasan individu dan cara memandang sesuatu lebih utuh. Keyakinan bahwa setiap manusia memiliki nilai-nilai positif dalam pikirannya maka hendaknya hal tersebut tetap dipertahankan. Ketika lebih dikaji secara mendalam terdapat keterikatan yang kuat antara bagaimana kewajiban seorang manusia dalam bermasyarakat dengan bagaimana menjalani hidup sesuai kaidah-kaidah keagamaan (Hartaka, 2019).

Rahasia kedatangan manusia sama rahasianya dengan kepergian manusia. Orang yang belum memiliki pengetahuan tentang kerahasiaan kedatangan dan kepergian manusia dan tujuan kedatangan manusia, maka sesungguhnya masih gagal dalam kelahiran ini dan harus lahir berulang kali (Yupardhi, 2013: 57). Mencermati 
hal ini, maka pendalaman terhadap ajaran Hindu sangat diperlukan sumber literasi sebagai acuan. literasi yang mendukung terbatas jumlahnya di Indonesia, sehingga kajian yang akan kita lakukan kurang komprehensip dan pengetahuan yang parsial sering menimbulkan kesalah-pahaman dan multi tafsir. Tentang pengamalan ajaran agama melalui pendalaman Sradha secara tegas dijelaskan dalam smrti.

Sruti tidak mudah dipahami tanpa bantuan dari para guru yang mapan dan literatur-literatur pendukung (Donder, 2006: 248). Maka pendalaman dapat dilakukan lebih mudah melalui smrti. Panca sradha yaitu lima pokok keyakinan Hindu bersumber dari kitab suci Manava Dharmasastra atau Veda Smrti juga terdapat dalam kitab suci Bhagavadgita, Sarasamuscaya, dan lainlain (Donder dan Wisarja, 2012: 59). Sesungguhnya Sradha saja tanpa kebhaktian tidaklah cukup, hal ini ditegaskan kembali dalam Bhagavadgita VII.22

Sa taya sraddhaya yuktas

Tasya raddhanam ihate

Labhate ca tatah Kaman

Mayai va vihitan hi ta

Terjemahan:

Diberkati dengan kepercayaan itu dia mencari penyembahan pada itu dan dari itu dia dapat apa yang di citacitakannya dan hasil mana adalah pemberian dari Aku sendiri (Mantra, 2018: 172).

Sloka diatas menunjukkan begitu besarnya penghargaan terhadap sradha (keimanan atau keyakinan) seorang pemuja, sebab pada esensinya bhaki itu akan terkabulkan oleh Tuhan Yang Maha Esa. Bila kita menelaah maksu sloka tersebut, maka bagi pendalaman Sradha dalam rangka pengamalan ajaran agama yang dikenal dengan istilah Dharma Sadhana. Dharma Sadhana artinya merealisikan (ajaran) Dharma dalam kehidupan sehari-hari. Tentang Dharma Sadhana, maharsi Vararuci yang dikenal pula di dalam Sarasamuccaya $8,9,10,11$ menyatakan sebagai berikut:

Iking tang jnama wwang, ksanika swabawa ta ya, tan pahi lawwan kedapning kilat, durlabha towi, matangnya ponga-kena ya ri kagawayanning dharmasadhana, sakarananging manasanang sangsara, swargaphala kunang.

Terjemahan:

Alangkah cepat dan pendeknya kehidupan sebagai manusia ini tak bedanya dengan sinarnya kilat, dan sangat susah pula untuk didapat. Oleh karena itu berusaha benar-benarlah untuk berbuat berdasarkan (sadhana) dharma (kebenaran) untuk menghapuskan kesengsaraan hidup guna mencapai sorga.

Hana pwa tumemung dadi wwang, wimukah ring dharmasadhana, jenek ring arthakama arah, lobhambeknya, ya ika kabancana ngaranya.

Terjemahan:

Celakalah ia yang mendapatkan kesempatan menjelma sebagai manusia tetapi dalah hidupnya selalu ingkar akan ajaran-ajaran dharma (kebenaran) dan selalu mengejar harta dan kepuasan napsu belaka, serta berfikri tamak selalu.

Ikang manggih si dadi wwang, prasiddha weang ring dharmasadhana, tatan entas sangke sangsara, kabancana ta ngaranika. 
Terjemahan:

Celaka pulalah ia yang menjelma sebagai manusia serta mampu melaksanakan ajaran dharma tetapi kemampuan dan kesempatan itu tidak dipakai untuk melepaskan diri dari kesengsaraan.

Nihan mata kami mangke, manawi, manguwuh, mapitutur, ling mami, ikang arta, kama, alamken dharma juga ngulaha, haywa palangpang lawan dharma mangkana ling mami, ndatan juga angrengo ri haturnyan eweh sang makolah dharmasadhana, apa kunang hetunya.

Terjemahan:

Itulah sebabnya aku sekarang tidak jemu-jemu, terus menerus memberikan nasehat, kataku: jika mencari harta dan kepuasan napsu hendaknya selalu berdasarkan dharma (kebenaran), jangan ingkar akan dharma, demikian kataku, tetapi tidak ada yang menghiraukan sebab katanya "sangat sukar melakukan dharma. Dan apa pulalah gunanya! (Sudharta, 2009: 7-8).

Mengingat ajaran Dharma (agama Hindu) amat luas tentunya pengamalan praktis sangat diperlukan. merealisasikan ajaran agama dalam kehidupan sehari-hari, maka kita kembali mengikuti beberapa wahyu dalam pustaka suci. Bhagavadgita yang merupakan sabda Tuhan Yang Maha Esa menyatakan bahwa setiap orang hendaknya melakukan 4 hal, yaitu:

a. Abhyasa yang artinya untuk perbuatan baik lakukanlah dan biasakanlah hal itu,

b. Tyaga atau Vairagya yang artinya kendalikanlah atau tinggalkanlah perbuatan-perbuatan yang menjerumuskan hidup kita,

c. Santosa yang artinya beryukurlah terhadap karunia Tuhan Yang Maha Esa, memberikan kita kesempatan menjelma sebagai manusia untuk biasa memperbaiki diri dan kesadaran untuk meningkatkan kualitas hidup dan kehidupan kita untuk mencapai Jagadhita (kesejahtraan jasmaniah) dan Moksa (kebahagiaan sejati),

d. Sthitaprajna yang artinya hidup berkeseimbangan lahir dan batin, tidak terlalu bergembira bila memperoleh keberuntungan dan tidak putus asa bila menghadapi kemalangan atau kedukaan. Hidup yang stabil, berkeseimbangan lahir dan batin dapat digambarkan sebagai seorang pemain selancar (surfing) yang mahir. Bagaimanapun besarnya gelombang, ia hadapi dengan senyum simpul. Sekali-kali tenggalam digulung ombak, kemudian muncul tersenyum di atas gelobang. demikian pula kita menghadapi gelombang kehidupan (Ardiyasa, 2018).

Demikian antara lain pendalaman Sradha dalam rangka meningkatkan pengamalan Dharma, merealisasikan atau mewujudkan ajaran Dharma dalam kehidupan sehari-hari. Karena itu manusia disebut makhluk paling tinggi derajatnya dan mampu berbuat yang terbaik (Mas, 2012: 55). Usaha ini perlu dikondisikan sehingga umat beragama dapat semakin mantap melaksanakan ajaran agamanya.

\subsection{Karmaphala dalam Susastra Hindu}

Radhakrishnan dalam Budhitha (2019) menjelaskan Hinduisme adalah suatu warisan pemikiran apresiasi, hidup, dan bergerak seiring dengan 
pergerakan kehidupan itu sendiri, suatu warisan tempat setiap ras di India telah memberikan kontribusi khusus. Budaya hindu mempunyai persatuan tertentu, meskipun bila diamati secara seksama budaya itu terbagi ke dalam aneka ragam dan corak warna. Ini menjelaskan bahwa susastra Hindu di nusantara memiliki esensi yang serupa dengan sumber ajarannya. Termasuk tentang ajaran karmaphala yang ada dalam berbagai susastra nusantara.

Karma (adalah bahasa sanskerta dari urat kata $\mathrm{Kr}=$ membuat) berarti perbuatan. Menurut hukum sebab dan akibat (causality) maka segala sebab akan membawa akibat (Punyatmadja, 2019: 61). Doktrin karmaphala menjadikan agama Hindu dapat diterima oleh pemikiran rasional, karena mampu memberikan jawaban dari permasalahan kehidupan yang mendasar. Jika dijabarkan secara lebih kongkrit doktrin karmaphala yang terdapat dalam sumber-sumber suci Hindu mampu diterima oleh seseorang yang mempunyai pengetahuan rendah. Ini menandakan ajaran karmaphala begitu universal.

Donder dan Wisarja (2012) menjelaskan Hukum Karmapahla secara komprehensip terdapat dalam berbagai mantram dan sloka-sloka kitab suci Hindu. Untuk mempertebal keyakinan itu umat hindu mutlak harus mendalaminya melalui buku-buku tersebut. Mantram-mantram yang mengandung unsur doktrin karmaphala, yaitu:

a. Orang yang mati karena perbuatanya sendiri (Rgveda VIII.97.3)

b. Orang yang tidak giat berusaha (bekerja) selalu menderita (Rgveda VIII.3) c. Orang yang berdosa akan menderita (Atharvaveda X.1.5)

d. Setiap tindakan memiliki akibat (Rgveda V.12.5)

e. Perbuatan jahat menyebabkan kehancuran (Rgveda VII.52.2)

f. Kehidupan yang kekal diperoleh dari hasil perbuatan luhur (Rgveda I.110.4)

Mantram-mantram dalam smerti juga memuat tentang ajaran Karmaphala yang menjelaskan bahwa hukum karma itu berlaku pada siapa saja dan dimana saja. Hukum karma tidak pilih kasih, ia akan dengan tepat mengenai sasaran. Adapun matram-mantram dalam Manava Dharmasastra yang memuat tentang ajaran karmaphala sebagai berikut.

\section{Kamatmata na prasasta na caive hastya kamata kamyo hi vedadhigamah karmayogasca vaidikah}

(Manava Dharmasastra II.2)

Terjemahan:

Berbuat karena hanya ingin mendapatkan pahala adalah tak terpuji, tetapi sebaiknya berbuat tanpa keinginan, yang demikian inipun tidak dapat kita temui di dunia ini, karena ajaran Veda serta pelaksanaan kegiatan yang diajarkan oleh Veda itu sendiri juga didasari oleh rasa keinginan demikian.

Samkalpa mulah kamo vai yajnah samkalpa sambhavah vrata niyama dharmasca satve samkalpajah smrtah

(Manava Dharmasastra II.3)

Terjemahan:

Keinginan untuk mendapatkan pahala kakekatnya, didasarkan pada pemikiran bahwa perbuatan 
itu memang harus mendapatkan pahala dan sebagai kelanjutan dari pemikiran ini maka dilaksanakanlah upacara korban, janji sumpah serta ketentuan yang mengatur pengekangan dari semuanya dinyatakan tetap dilaksanakan, kegiatan itu akan mendapat pahala.

\section{Bhrtyanamupa rodhena yat karotyaurddhva dehikam tad bhavatya sukhodarkam jivatas ca mrtasya ca.}

(Manava Dharmasastra XI.10)

Terjemahan:

Jika seseorang tidak melakukan apa yang membahagiakan dirinya, di dunia lain nanti kerugian seperti itu yang seharusnya ia pelihara akan mengakibatkan keburukan baginya, baik selagi hidupnya maupun sesudah matinya (Pudja dan Sudharta, 2004: 30,552).

Paparan tentang Karmaphala juga termuat dalam susastra Hindu di nusantara. Hakekat dan makna yang terungkap senada dengan apa yang temuat dalam sruti. Melalui kerja (karma) maka tujuan yang dicapai merupakan hasil dari usaha tersebut. Nilai manusia terletak pada kerjanya atau perbuatannya. Manusia harus menyadari bahwa dampak dari kerja yang dilakukannya adalah dinikmati oleh manusia itu sendiri (Gorda, 2006: 89).

Karma Phala ngaran ika, Pahalaning gawe hala haju,

(Slokantara 68)

Terjemahan:

Karma Phala artinya akibat (phala) dari buruk (suatu) perbuatan (Karma)
Apan iking dadi wwang, uttama juga ya, nimittaning mangkana, wenang ya tumulung awaknya sangkeng sangsara, maka sadhanang subha karma hinganing kottamaning dadi wwang ika

(Sarasamuscaya 4)

Terjemahan:

Sesungguhnya menjelma sebagai manusia ini adalah suatu hal yang utama, karena hanya manusialah yang dapat menolong dirinya sendiri dari kesengsaraan, yaitu dengan jalan berbuat baik. Itulah keuntungan menjelma menjadi manusia (Sudharta, 2009: 5).

Asing sagawenya dadi manusa, ya ta iningetaken de Bhatara Widhi, apan sira pinaka paracaya bhatara ring chubachuba kramaning janma

(Wrhaspati Tattwa, 22)

Terjemahan:

Segala (apa) yang diperbuat di dalam penjelmaan (menjadi) manusia, (semua) itulah yang dicatat oleh Bhatara Widhi (Tuhan Yang Maha Kuasa) karena dia saksi (dari) baik buruk (amal dosa) perbuatan manusia

Bhatara Dharma ngaran ira
Bhatara Yama, sang
kumayatnaken shubashuba
prawrtti nikang sekala janma

(Agastya Parwa 355.15)

Terjemahan:

Bhatara Dharma (juga) bergelar Bhatara Yama (pelindung keadilan 
yang mengamat-amati (mengadili) baik buruk perbuatan manusia. Baik buruk dari (karma) itu akan memberikan akibat yang besar terhadap kebahagiaan atau penderitaan hidup manusia (Punyatmadja, 2019: 63)

Manusia harus menyadari bahwa ia tidak akan luput dari pengaruh hukum karma, oleh karena itu selama manusia masih hidup karma akan senantiasa jadi bagian yang tak terpisahkan. Dari karma pula mendatangkan phala yang bermacam-macam pula sesuai dengan karma yang dilakukan. Hasil ini pasti dipetik oleh yang melakukan, kalau tidak hari ini, mungkin akan diterima di kehidupan mendatang. Manusia harus tekun melaksanakan karma baik dengan mengacu pada dharma yang termuat dalam susastra suci yang ada. Niscaya Tujuan terakhir yang merupakan sradha kelima yaitu Moksa akan dapat diraihnya.

\subsection{Relevansi Ajaran Karmaphala dalam Peningkatan Kesadaran}

Karmaphala Tatwa atau

Karmaphala Sradha sebagai salah satu Sradha dari Panca Sraddha (Lima Keimanan) begitu terasa pengaruhnya dalam akitivitas keseharian manusia. Penagruh Karma itu pulalah yang menentukan corak serta nilai daripada watak manusia. Oleh karena itu bermacam-macam jenisnya dan tak terhitung banyaknya, maka watak manusiapun beraneka macam pula ragamnya karma yang baik menciptakan watak yang baik dan karma yang jelek akan mewujudkan watak yang jelek dan jahat (Puniyatmadja, 2019: 63).

Kehidupan manusia jaman sekarang yang sudah memasuki era digital, dimana semua manusia mulai sibuk dengan kepentingan masingmasing tentu saja secara langsung maupun tidak langsung berdampak kepada self-awareness tersebut. Di era yang serba cepat dan instan ini, orang tidak lagi memperhatikan pikiran, perasaan dan perilaku diri, serta dampaknya terhadap orang lain. Banyak orang yang justru terjebak dalam penerimaan kemunculan era digital yang menjadikan manusia menjadi tidak manusiawi seperti memudar atau bahkan menghilangnya nilai-nilai etika, moral dan budaya (Somawati dan Made, 2019).

Kenyataan modernism dalam ruang-ruang sosial, membawa manusia modern dengan pengetahuan rasionalnya. Dalam hubungan dengan rasionalitas, modernism menegaskan kedudukan rasio dalam wacana kehidupan modern dan postmodernisme sebagai hal yang di nomor satukan. Weber dalam mengamati perkembangan masyarakat barat yang modern, sebagai peningkatan rasionalitas. Hat tersebut tercermin dalam tindakan ekonomi individu setiap hari, bentuk-bentuk organisasi sosial dan termasuk pada evolusi musik barat (Budhita, 2019: 121)

Dharma sebagai tujuan hidup yang utama, dan mengabdi terhadap sesame makhluk dan beramal saleh untuk kesejahteraan sesama makhluk yang menjunjung tinggi keadilan dan kebenaran, maka orang itu akan mendapat berkah dari Ida Sang Hyang Widhi Wasa, yakni kebahagiaan akhirat (sorga) (Punyatmadja, 2019: 65). Perbuatan adalah suatu rangkaian atau perjalanan yang panjang ini akan berakhir bila seseorang telah dapat bersatu dengan Sang Pencipta. Hal ini dijelaskan dalam kitab Svetasvatara Upanisad, sebagai berikut: 
Arabhya karmani guna vitani, bhavams ca sarvan viniyojayed yah, tesam abhave krta-karmanasah karmaksaye yati sa tattvato'nyah

(Svetasvatara Upanisad VI. 4) Terjemahan

Siapakah, Ketika mulai dengan pekerjaan-pekerjaanya yang berhubungan dengan triguna, membagi semua keberadaan. Pada keadaan tidak hadirnya guna ini, ada penghancuran dari pekerjaan yang sudah dilakukan dan pada penghancuran dari pekerjaan dia melanjutkan, sesunggunya, yang lain dan beberapa dari apa yang sudah dihasilkan (Radhakrishnan, 2008: 582). (Radhakrishnan 2008)

Sloka Upanisad di atas menjelaskan, bahwa seseorang memutuskan rangkaian hukum karmaphala bila ia telah dapat melaksanakan kerja atau aktivitas ditujukan pada Iswara semata. Bila pekerjaan bukan untuk kepentingan diri sendiri tetapi untuk menyenangkan Tuhan, pekerjaan kita tidak akan mengikat kita lagi dan kita akan bebas. Sesungguhnya upaya yang dilakukan oleh setiap manusia adalah menciptakan jalinan tali kasih antara manusia dan Tuhan secara terus menerus yang tidak pernah putus. Sebab itulah satu-satunya hubungan yang kekal, sedangkan hubungan dengan benda-benda duniawi yang bersifat material adalah hubungan tidak kekal (Yupardhi, 2013: 63)

\section{Bahyasparsesv asaktatma vindaty atmani yat sukham sa brahmayogayuktatma sukham aksayam asnute}

(Bhagavadgita V.21)

Terjemahan:

Bilamana jiwa tidak lagi terikat dengan hubungan dari luar (obyekobyek) orang menemui kesenangan yang ada di dalam atma. Orang yang demikian itu yang menunggal dengan Tuhan merasai kebahagiaan yang tak padam-padamnya (Mantra, 2018: 126)

Badan-badan itu diperoleh sesuai dengan subha dan asubhakarmanya. Jika manusia selalu berbuat seperti binatang, maka badan selanjutnya akan diperoleh badan binatang. Hukum karmaphala dan samsara menjadi wujud cinta kasih Tuhan dalam wujud hukum. Antara Brahman dan Atman memiliki hubungan yang sangat erat, Brahman menyaksikan perbuatan manusia dari atman. Setelah diamati atman tidak tepat dalam badan tersebut, maka kelahiran selanjutnya akan diberikan badan fisik lain yang sesuai dengan karakter perbuatannya. Upanisad juga memuat tentang karma yang baik punyakarma (sadhukari) dan karma yang tidak baik (papakarma)

“... Punyo vai punyena karmana bhavati, papah papeneti ..."

(Brhadaranyaka Upanisad III.2.13) Terjemahan

“... Apa yang mereka katakana dalah karma dan apa yang mereka puji adalah karma, sesungguhnya seseorang menjadi baik karena perbuatan baik dan menjadi jahat karena perbuatan jahat ... (Radhakrishnan, 2008: 161-162)".

Sivananda (1993) menerangkan ada tiga macam karma yang dibedakan atas dasar waktu diterimanya phala oleh yang melakukan, yaitu Sancita (timbunan karma), Prarabdha (karma menyuburkan), dan Kriyamana atau Agami (rangkaian karma). Sancita adalah semua timbunan karma masa lalu, yang baginya terlihat ada karakter manusia, pada kecenderungankecenderungannya, pembawaan, kemampuan, dan keinginan-keinginan. Prarabdha adalah bagian dari karma masa lalu yang harus 
dipertanggungjawabkan oleh tubuh sekarang ini, yaitu bagian dari Sancita Karma yang memperngaruhi kehidupan manusia pada inkarnasinya yang sekarang, yang siap dipetik yang tak dapat dihilangkan atau dirubah. Ia hanya habis dengan alami, karena membayar hutang-hutang masa lalu, Prarabdha karma ialah karma yang telah dimulai dan benar-benar memikul buahnya, dan dipilih dari timbunan Sancita Karma. Kriyamana merupakan karma yang sekarang sedang dibuat bagi masa depan, yang juga disebut agami atau wartamana karma.

Demikian beberapa jenis Karma yang dilakukan oleh manusia sepanjang kehidupnya. Karma ini mempengaruhi kehidupan dan kelahiran seseorang di masa yang akan datang. Berikut kami kutipkan uraian pengaruh Karma terhadap kelahiran seseorang dalam Chandogya Upanisad V.10.8-10.

"Mereka yang melakukan perbuatan baik di sini akan segera memperoleh kelahiran yang baik, kelahiran sebagai Brahmana, kelahiran sebagai Kstriya atau kelahiran sebagai Vaisya. tetapi mereka yang perbuatannya di sini jahat, kelahirannya sebagai anjing, babi atau Candala"

"Dia yang mencuri emas, yang minum memabukkan, yang mencemarkan tempat tidur guru, yang membunuh Brahmana, yang empat dan termamsuk yang kelima adalah yang bergaul dengan orang seperti itu"

"Tetapi dia yang mengerti kelima api ini tidak akan tercemar oleh kejahatan, bahkan walalupun dia bergaul dengan mereka. Dia menjadi murni, bersih memperoleh dunia kebajikan, ya, dia yang mengerti hal ini (Radhakrishnan, 2008: 334)".

Menyimak terjemahan sloka tersebut merupakan ilustrasi cerita yang terdapat dalam kitab-kitab Itihasa dan Purana seperti kematian raja Dasaratha, kematian Rsi Bhisma dan lain-lain. Pengalaman empirik kejadian kecelakaan, kasus pembunuhan, dan lain-lain, maka sesungguhnya kita berusaha berpegangan kepada ajaran Karmaphala ini untuk mengendalikan diri. Menghindarkan dari perilaku buruk (asubhakarma) serta berusaha sebanyakbanyaknya menabungkan karma baik untuk kebaikan kehidupan kita kini, nanti dan bahkan untuk penjelmaan di masa yang akan datang. Kitab Sarasamuccaya (110) menyatakan sebagai berikut.

Nihan ta prakaraning aryakena, lwirnya, si tan pamituhu ri hana ning paraloka, lawan phalaning subhasubhakarma, kanindan sang hyang weda, kanindaning dewata. Irsya, si pujyan mawak, ai ahangkara, krodha, panasbhara, rengorengon, samangkana aryanaken, dohakena sangkeng manah.

Terjemahan:

Sikap yang harus kita jauhkan ialah ketidakpercayaan akan dunia akhirat, ketidakpercayaan pada pahala dari baik buruknya perbuatan (karmaphala), mencela Pustaka suci Weda, memaki Tuhan, iri hati, suka memuji diri sendiri, angkara, pemarah, suka bicara menyinggung perasaan, suka mendengar yang tidak patut di dengar. Semua itu patut dijauhkan dari pikiran (Sudharta, 2009: 52).

Di dalam kehidupan bermasyarakat terdapat nilai dan norma 
yang berlaku secara umum serta harus kita hormati dan dijalankan sebagai warga masyarakat yang baik. Hukum pun ada untuk mengatur perilaku warga masyarakat dengan memaksa untuk mengendalikan setiap individu yang memiliki berbagai latar dan pemikiran yang berbeda. Salah satu kunci ketenangan jiwa dalam berkehidupan seseorang adalah kemampuan orang tersebut mengendalikan dirinya terhadap aspek kehidupan yang dijalaninya. Sebagaimana Dr. Wayne Dyer pernah mengatakan bahwa anda tidak bisa memiliki damai bathin selama pengendalian kehidupan anda ditempatkan di luar diri (Atmaja, dkk, 2010: 30-31).

Kuatnya kemauan diri untuk mampu mengendalikan dan menguasai diri kita sendiri, ialah sebuah keputusan yang harus segera dilakukan bukan hanya saat momen kemarahan menguasai pikiran, namun dalam segala kondisi. Di era new normal seperti sekarang ini tentu tantangannya akan semakin berat, tetapi kita harus menyadari sejak awal, sehingga telah terlatih untuk menguasai diri tanpa harus menunggu melakukan tindakan tanpa berfikir panjang, ucapan keliru termasuk berfikir sebagai jalan awal melakukan tindakan. Atmaja, dkk (2010) menguraikan Langkah-langkah mengendalikan diri agar tidak terjerumus kedalam dosa yang akan berpengaruh pada phala kita.

1. Belajarlah untuk bersabardan mampu menahan emosi,

2. Usahakan untuk bersikap tenang pada saat kita menghadapi konflik rentangan sikap orang lain,

3. Berusahalah untuk bisa menghormati atau menghargai orang lain,

4. Tumbuhkan sikap pengertian dan pola pemahaman yang begitu mendalam kepada keadaan atau pertanyaan yang diungkapkan orang lain,

5. Cobalah untuk menumbuhkan sikap tidak mudah terpengaruh atas sikap yang bisa memancing kemarahan besar dari dalam diri kita, sehingga kemarahan diri kita, tidak mudah dikuasai atau terbawa arus oleh emosi orag lain

6. Berikalah pemahaman yang baik tentang keadaan atau situasi pelik yang sedang kita hadapi, dengan mengemukaan kata-kata yang tidak membangkit-bangkitkan rasa kesal atau amarah orang lain.

Tingkah laku yang baik menujukkan bahwa kita sebagai makhluk berwiweka mampu melakukan disiplin pikiran, menjaga perkataan, dan mengendalikan perbuatan. Identitas ini menjadi perilaku spiritual sesungguhnya. Ia yang menaburkan perbuatan akan memetik kebiasaan, ia yang menebar kebiasaan akan menerima karakter, ia yang menunjukkan karakter akan memperoleh buah. Oleh sebab itu, buah yang kita terima saat ini merupakan tatanan kita lakukan sebelumnya. Untuk dapat melepaskan apa yang telah kita bangun dengan pengetahuan yang dibarengin implementasi pengetahuan tersebut. Ini merupakan sebuah sistem atau hukum yang telah dibuat dan tidak dapat dhindari oleh siapapun.

\section{SIMPULAN}

Ajaran Sradha yang merupakan keyakinan dasar umat Hindu yang senantiasa dipegang teguh dalam menjalani kehidupan keseharian baik secara pribadi, keluarga, masyarakat maupun berbangsa dan bernegara. Karmaphala Sradha harus dapat dijadikan pegangan dalam kehidupan dengan memahami, mendalami dan mengaktualisasikan ajaran luhur untuk mencapai tujuan. Pemahaman terhadap ajaran Karmaphala Sradha berporos pada susastra suci Veda dan ajaran Hindu lainnya serta pengalaman empirik di masing-masing 
individu saat menjalani kehidupan keseharian.

Dalam rangka meningkatkan pendalaman masih harus ditingkatkan secara kualitas maupun kuantitas. Dewasa ini kita memerlukan banyak filolog (ahli) Sanskerta dan Jawa Kuno, ahli-ahli filsafat, sastra, sejarawan, hukum Hindu dan lain-lain. Tidaklah tepat kita berpangku tangan dan hanya menunggu lembaga agama untuk berbuat. Upaya pendalaman secara kolektif harus terus digalakkan dikalangan umat Hindu. Doktrin karmaphala menjadikan agama Hindu dapat diterima oleh pemikiran rasional, karena mampu memberikan jawaban dari permasalahan kehidupan yang mendasar. Jika dijabarkan secara lebih kongkrit doktrin karmaphala yang terdapat dalam sumber-sumber suci Hindu mampu diterima oleh seseorang yang mempunyai pengetahuan rendah. Ini menandakan ajaran karmaphala begitu universal.

Implementasi ajaran Karmaphala Sradha sejatinya ialah pegangan guna pengendalian diri dalam berperilaku, sehingga membawa pribadi kepada kebahagian, pada keluarga membawa keharmonisan, dan masyarakat menciptakan yang kesejahteraan dan kemakmuran sesuai dengan dharma. Dalam era new normal ini, kondisi dalam kehidupan religius bermakna manusia sebagai umat beragama kembali pada ajaran agamanya dengan merealisasikan ajaran suci Tuhan Yang Maha Esa.

\section{DAFTAR PUSTAKA}

Ardiyasa, I. N. S. (2020). MAKNA FILOSOFI HARI RAYA GALUNGAN PADA ERA GLOBALISASI. Genta Hredaya, 2(1).

Atmaja, I Made Nada, dkk. 2010. Etika Hindu. Surabaya: Paramita.

Buditha, I Nyoman. 2019. Manusia, Agama dan Sastra. Yogyakarta: DEEPUBLISH.
Donder, I Ketut. 2006. Brahmavidya: Teologi Kasih Semesta Kritik Terhadap Epistemologi Teologi, Klaim Kebenaran, Program Misi, Komparasi Teologi, dan Konversi. Surabaya: Paramita.

Donder, I Ketut dan I Ketut Wisarja. 2012. Teologi Sosial: Persoalan Agama dan Kemanusiaan Perspektif Hindu. Surabaya: Paramita.

Gorda, I Gusti Ngurah. 2006. Etika Hindu dan Perilaku Organisasi. Denpasar: STIE Satya Dharma.

Hartaka, I. M. (2020). MEMBANGUN SEMANGAT KEBANGSAAN PERSPEKTIF ETIKA HINDU. Genta Hredaya, 3(2).

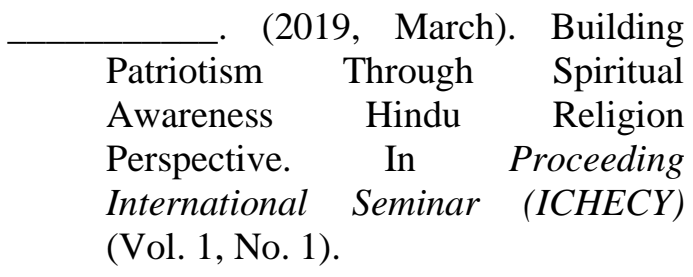

Mantra, Ida Bagus. 2018. Bhagavadgita: Naskah Sanskerta, Alih Bahasa dan Penjelasan. Denpasar: ESBE Buku.

Mas, A.A. Gede Raka. 2012. Runtuhnya Kemuliaan Manusia Menurut Perspektif Hindu. Surabaya: Paramita.

Pudja, Gede dan Tjokorda Rai Sudharta. 2004. Manava Dharmasastra (Manu Dharmasastra) atau Veda Smerti-Compendium Hukum $H i n d u$. Surabaya: Paramita.

Punyatmadja, Ida Bagus Oka. 2019. Panca Sradha. Denpasar: ESBE Buku.

Radhakrishnan, S. 2008. Upanisad Upanisad Utama. Surabaya: Paramita. 
Saifuddin, Ahmad. 2019. Psikologi Agama: Implemetasi Psikologi Memahami Prilaku Beragama. Jakarta: Prenadamedia Group.

Segara, I Nyoman Yoga. 2019. Ahimsa dalam teropong Filsafat Antropologi. Denpasar: CV. Setia Bakti.

Sivananda, Sri Svami. 1993. Intisari Ajaran Hindu. Suarabaya: Paramita.

Somawati, A. V., \& Made, Y. A. D. N. (2019). IMPLEMENTASI AJARAN TRI KAYA PARISUDHA DALAM MEMBANGUN KARAKTER GENERASI MUDA HINDU DI ERA DIGITAL. Jurnal Pasupati Vol, 6(1).
Titib, I Made. 2006. Veda Sabda Suci Pedoman Praktis Kehidupan. Surabaya: Paramita. 2011. Bahan Ajar Veda. Denpasar: IHDN Denpasar.

Yupardhi, W. Sayang. 2013. Manusia Perspektif Teologi Universal. Surabaya: Paramita. 